ENGINEERING, CONSTRUCTION AND ARCHITECTURAL

MANAGEMENT

DOI: 10.1108/ECAM-05-2020-0375

\title{
Contribution of Procurement Capacity of Public Agencies to Attainment of Procurement Objectives in Infrastructure Procurement
}

a Patrick Manu, ${ }^{b}$ Richard Ohene Asiedu, ${ }^{c}$ Abdul-Majeed Mahamadu, ${ }^{c}$ Paul
Olomolaiye, ${ }^{c}$ Colin Booth, ${ }^{d}$ Emmanuel Manu, e Saheed Ajayi, and ${ }^{f}$ Kofi Agyekum

${ }^{a}$ Department of Mechanical Aerospace and Civil Engineering, The University of Manchester, Manchester, M13 9PL, United Kingdom

${ }^{b}$ Department of Building Technology, Koforidua Technical University, Koforidua, Ghana

${ }^{\circ}$ Faculty of Environment and Technology, University of the West of England, Bristol, BS16 $1 Q Y$, United Kingdom.

${ }^{d}$ Department of Construction Management, Nottingham Trent University, Nottingham, United Kingdom

e School of Built Environment and Engineering, Leeds Beckett University, Leeds, United Kingdom

${ }^{f}$ Department of Construction Technology and Management, Kwame Nkrumah University of Science and Technology, Kumasi, Ghana

Corresponding author: Patrick Manu

Email: Patrick.Manu@manchester.ac.uk

Telephone: 00441613067572 


\section{ABSTRACT}

Purpose: Effective procurement of infrastructure is linked to the attainment of the sustainable development goals set by the United Nations. While the capacity of organisations is generally thought to be related to organisational performance, there is a lack of empirical insights concerning the contribution of procurement capacity of public organisations towards the attainment of procurement objectives in infrastructure procurement. Thus, it is unclear which aspects of the capacity of public procurement organisations contribute the most to the attainment of procurement objectives in the procurement of infrastructure. This research sought to address this gap.

Design/methodology/approach: The research used a survey of public procurement professionals which yielded 590 responses.

Findings: Exploratory factor analysis of 23 organisational capacity items revealed three components of organisational procurement capacity: 'management of the procurement process'; 'human and physical resources'; and 'financial resources and management'. Multiple regression modelling of the relationship between the components and the attainment of 12 procurement objectives further reveals that there is a significant positive relationship between the three components and all the objectives. However, 'management of the procurement process' emerged as the greatest contributor to the attainment of seven objectives, whereas 'human and physical resources', and 'financial resources and management' were the greatest contributor to the attainment of one objective and four objectives, respectively.

Originality/value: The study provides strong empirical justification for investment in the development of procurement capacity of public agencies involved in procurement of infrastructure. Furthermore, procurement capacity development of specific capacity components can be prioritised based on the relative contribution of capacity components to the attainment of desired procurement objectives. This should be useful to government policy makers as well as multilateral organisations that fund infrastructure and procurement reforms in various countries.

Keywords: organisational capacity; procurement capacity; procurement objectives; public organisation; public procurement; infrastructure.

\section{Introduction}

Several scholarly findings, beginning with the influential work by Aschauer (1989) and policy discussions (e.g., World Bank, (1994)) have all identified adequate infrastructure delivery as a vital vehicle for economic development (Calderon and Serven, 2008). This, according to the United Nations Economic and Social Council (UNESC) (2016) is also supported by the express need for essential infrastructure like roads, hospitals, water, power generation and schools, which are precursors of achieving the Sustainable Development Goals (SDGs) set by the United Nations. Although the SDG 9 explicitly talks about building resilient infrastructure, all the remaining goals are underpinned by infrastructure development (The Economist Intelligence Unit Department, EIUD, 2009). This assertion was reiterated by a Senior Policy Analyst (Virginie Marchal) in the OECD's Environment Directorate who indicated that infrastructure is really at the centre of the delivery of the SDGs (EIUD, 2009). According to Parente and Prescott (2000), infrastructure for the provision of public services 
productivity, industrialisation and commerce. The Global Construction Perspectives and Oxford Economics (2013) forecasts a 70 percent rise in world-wide construction output by the year 2025. It is anticipated that a greater share of the expected infrastructure growth would be realized in developing/emerging economies while investment contributions are made to bridge the infrastructure gap.

Governments employ public procurement processes to deliver vital infrastructure to support socio-economic development at different scales. Public procurement involves several activities including: planning, identifying needs, inviting of tenders, tender evaluation, awarding contract, contracting and contract administration (United Nations Office for Project Services (UNOPS), 2014). Procurement within the public sector is estimated at fifteen percent of the gross domestic product (GDP) of nations globally (Organisation for Economic Co-operation and Development (OECD) and World Bank, 2004; United Nations Development Programme (UNDP), 2010). However, it may account for about seventy percent of GDP in developing nations (Anvuur et al., 2006; UNDP, 2010; Asiedu and Alfen, 2014). Thus, the greater part of the budget of most developing economies could be said to be spent on public procurement activities (African Development Bank (AfDB), 2013).

An efficient public procurement process is an important vehicle for realising infrastructure (Lewis-Faupel et al., 2016). Consequently, procurement reforms have been promoted and supported by institutions such as the United Nations Office for Project Services (UNOPS), United Nations Development Programme (UNDP) and World Trade Organisation through capacity development initiatives with funding as well as design of frameworks and policies (OECD, 2002, 2006; Evenett \& Hoekman, 2005; UNDP, 2006; World Bank, 2013). The nature and the size of public procurement makes it an important determinant of the social and economic development of various countries worldwide. Within the developed and developing economies, governments use procurement to attain key policy objectives like the maximization of competition, economic goals, environmental protection or green procurement, social goals, and the likes (Offei et al., 2016). To attain these objectives, the governments must strive hard to build the capacity of the agencies through which public procurement is undertaken.

It is established that the strengthening and usage of national procurement systems is a key factor in scaling up for more effective aid. According to the UNDP (2006), the commitment to this assertion was reaffirmed by The Paris Declaration and the Accra Agenda for Action to carry out diagnostics, develop sustainable reforms and monitor implementation, as well as commit sufficient resources to supporting and sustaining medium and long-term procurement reforms and capacity development. The procurement capacity includes individual, organisational and environmental elements (UNDP, 2006). Jensen (2009) noted that to widen the procurement capacity building of institutions, it is important to pay attention to human resources as well as intensification of managerial systems.

With the benefits of strengthened national public procurement not restricted to arguments relating to aid delivery, public procurement of goods, services and works accounts for a significant amount of national expenditures. Globally, public

procurement is estimated at about $15 \%$ of the world's GDP, but in some developing countries, it may account for as much as 70\% (International Trade Centre, ITC, 2014). This is particularly the case in Least Developed Countries (LDCs) and post conflict countries, where underdeveloped private sectors require public sectors to play a major role in the delivery of services and the provision of much needed economic 
infrastructure (UNDP, 2006). Improved public procurement capacity will therefore impact on economic and social results. Unfortunately, this is not the case as several challenges have been identified to be associated with the implementation of public procurement (Okunlola et al., 2011; Mensah and Ameyaw, 2012; World Bank, 2013; Addo-Duah et al., 2014; de Mariz and Abeillé, 2014). Notwithstanding the existence of these challenges, the extent of impact of organisational procurement capacity on effective procurement of infrastructure by public institutions has attracted limited empirical investigation.

This study therefore investigates the contribution of procurement capacity of public agencies to the attainment of procurement objectives in the procurement of infrastructure. This has become important because adequate capacity is an important component of any sound public procurement system. In particular, the research seeks to establish the aspects of organisational procurement that contribute the most to the attainment of procurement objectives in infrastructure procurement. The paper first discusses the significance of infrastructure to socio-economic development and then reviews literature on procurement capacity and procurement objectives. Subsequently, the research presents the research methodology, findings, discussion, and conclusion.

Significance of Infrastructure to Socio-Economic Development McCarthy (2006) describes infrastructure as the physical structures and the networks that offer significant services for the social and economic needs of the public. It comprises: transport infrastructure (e.g. airports, bridges, roads, seaports and railway); utilities infrastructure (e.g. water, gas, and electricity supply systems); and social and health infrastructure (e.g. hospitals and schools) (Newell et al., 2009). Infrastructure has been observed to affect economic growth in two keyways - directly enhancing activity and supporting productivity. It is also significant in generating services, reducing trade and operation costs, furthering economic activities, minimizing production costs, and improving market competitiveness. Research regarding the role of infrastructure to productivity, output and welfare abound (e.g. Rioja, 1999; Cadot et al., 2006; Lakshmanan, 2011). The attention of a significant portion of empirical research regarding the significance of the provision of municipal infrastructure has focussed on its impact on the rise in productivity. Majority of the research reveal a positive impact of infrastructure on productivity (e.g. Cadot et al., 2006; Sahoo and Dash, 2009). Other studies assessed the consequences of infrastructure on income disparities (e.g Calderón and Servén, 2014). According to Calderón and Servén (2008), the underlying reason is that the provision of infrastructure is expected to have an uneven effect on the living standards of the poor by increasing the worth of their assets. Additionally, provision of infrastructure is likely to lower the cost of transaction for accessing the markets by the poor. Other related studies have also examined the consequences of some specific infrastructure projects on the less privileged (e.g. Van de Walle, 2009; Gebregziabher et al., 2009).

Investment in infrastructure is considered very significant in every country. Studies conducted by Oxford Economics (2017) suggest that USD \$94 trillion investment is required between 2016 and 2040 to bridge the gap in infrastructure. Investment yearly is therefore expected to be around USD \$3.7 trillion which is 19\% higher than the current investment being made. To meet this global need, the current annual GDP allocation to infrastructure must be increased from 3.0\% to 3.5\%. The Americas and Africa currently have the largest infrastructure gap while Oxford Economics (2017) forecast suggest that Asia will continue leading the global infrastructure market. It is expected that up until 2040, the Americas and Asia will account for $22 \%$ and $45 \%$ of 
investment in infrastructure worldwide. Consequently, by 2040, India, China, Japan, and the US alone will constitute over fifty percent of investment in infrastructure worldwide. The forecast further suggest that funding required in the Americas and Africa are $47 \%$ and $39 \%$ respectively; greater than what exist under current trends. At present, while the African region offers substantial growing potential, its infrastructure market remains small in absolute terms considering the region only accounts for $6 \%$ of worldwide infrastructure investment. Electricity and roads which are the two most important sectors together account for more than $66 \%$ of worldwide funding requirement. It is projected that an estimated USD \$1.9 trillion will be required in order to meet the SDGs for sanitation and drinking water while provision of global access to electricity by 2030 will be daunting for the world's poorest countries requiring about USD \$3.9 trillion of investment. The deduction therefore is that countries worldwide will need to spend heavily on infrastructure to satisfy the populace and underpin productivity throughout their economies. In doing this, effective procurement is needed. However, how can effective procurement be enforced if the procurement capacities of the various agencies are not enhanced? This question therefore leads to the subsequent section under the literature review where procurement capacity is discussed.

\section{Procurement Capacity}

Capacity can be described as the ability of organisations, people, and society to effectively manage their affairs (OECD, 2006). The UNDP (2010) describes it in terms of procurement capacity development as the way organisations and individuals over a period of time acquire, strengthen, and sustain their abilities to attain their objectives for development. The UNDP (2006) offers a procurement capacity assessment framework which considers procurement capacity as composing the individual aspect (i.e. staff experience, expertise and level of understanding); the organisational aspect (i.e. the processes, policies and schemes inside an organisation that help procurement functions); and the enabling national environment.

The organisational aspect is mostly based on human resources and the creation of an enabling organisational environment as well as intensification of managerial systems for wider institutional capacity building (Jensen, 2009). The following areas of organisational capacity are considered as part of the Millennium Challenge Corporation's (MCC) procurement maturity model: staffing (recruiting); human resources capabilities development (mentoring, training); professional improvement (promotion, retaining); risk management; procurement organisation; information systems management; procurement management; leadership and organisational culture; and performance management (Meyer, 2014). The OECD and World Bank (2004) similarly highlight the following as key organisational areas: organisational structure; staffing profile; budgeting and planning process; information technology

infrastructure and skills; and human resources function. The UNDP (2006) summarises organisational procurement capacity based on eight core areas which are presented in Table 1. The core areas include leadership, policy framework, mutual accountability mechanisms, public engagement, human resources, financial resources, physical resources, and environmental resources. A brief description of the various areas has further been presented in Table 1. Building a sound capacity in procurement in is imperative for successful project implementation and the attainment of procurement objectives, as well as its sustainability. The subsequent section thus conducts a review on procurement objectives. 


\section{Procurement Objectives}

Analogous management objectives for public procurement exist in many countries across the globe (e.g. Jones, 2002; Qiao and Cummings, 2003). For instance, following a forum by members of the Asia-Pacific Economic Cooperation (APEC), the expert groups in procurement put together a number of values or objectives such as open and efficient competition, transparency, fairness, value for money (VfM), accountability and due process (Rothery, 2003). Other jurisdictions include procurement principles such as compliance, promotion of equality, diversity and opportunity, private sector participation and standardisation of procurement procedures (e.g. Ndou, 2004; Kwak et al., 2009). Notwithstanding, the suitability of the principles are decided by respective countries taking cognisance of the exact features of the economies and the trade-offs in adopting those specific measures.

Professionalism in public sector procurement relates to the educational attainment of procurement staff and the professional manner in which they discharge their duties (Raymond, 2008). Breaches in procurement is the result of lack of professionalism which ultimately impedes compliance. Capacity issues relating to the procurement of infrastructure have also been attributed to poor performance in developing countries. These issues include lack of technical expertise and competencies, which often result in non-conformance to due process, and misapplication of procurement laws and regulations (World Bank, 1995, 2000, 2003).

Value for money (VfM) is an important objective in public sector procurement, considering governments' resource constraints. VfM, which is one of the fundamental objectives of procurement, is the best combination of quality principles and total life cycle costs (OGC, 2007). Globally, best practices include the strategic use of procurement to attain VfM and sustainability (UNDP, 2010). Sustainable procurement encapsulates the attainment of VfM and consideration of whole life cycle impacts of products and services on the environment and social order at large. In recent years, sustainable procurement has been promoted in countries like United Kingdom through an emphasis on social value considerations in public procurement bids (see Wright, 2015; Awuzie and McDermott, 2016). For procurement of infrastructure to be sustainable, there is a need for the use of contracts and performance management to meet social, environmental, and economic goals (Laryea et al., 2013). These are often achieved through specification, contractor selection and award principles that are based on sustainability and whole life cycle considerations (OGC, 2007).

Contractors

are expected to be selected competitively to ensure price optimisation.

Competitiveness inspires a bigger supplier engagement at the tendering phase through advertising, sourcing reviews, prequalification and open processes. Procurement requests must be widely circulated to enhance the possibility of receiving a good response from the market resulting in the award of competitively priced contracts.

The principle of accountability in procurement ensures procurement personnel take responsibility for their decisions and choices during the procurement process. This accountability in public procurement is paramount given that infrastructure procurement remains a key avenue for corrupt activities to occur (Locatelli et al., 2017; Owusu et al., 2019). Similarly, the principle of transparency ensures that procurement rules and requirements of the procurement process are publicised to all prospective suppliers prior to they being applied. However, the apparent lack of record keeping and data collection within public institutions can hinder efficient monitoring of the procurement process targeted at enhancing transparency (Bolton, 2006). Public procurement should also be carried out in an equitable manner that reflects fairness. 
Public procurement reflecting equity is concerned with fairness or economic justice or equitable treatment to all participants. Good public procurement is impartial, consistent, and therefore reliable (Adewole, 2014).

Building on the above review of literature, the next section conceptualises the relationship between procurement capacity of public agencies and attainment of procurement objectives in the procurement of infrastructure.

\section{Conceptual Framework}

To clearly conceive the phenomenon under investigation, it is advocated that the investigation must be underpinned by appropriate literature and reference to existing and similar knowledge (Saunders et al., 2007). This provides a theoretical basis as well as practical guide for the conduct of the investigation. Similarly, UNDP $(2007,2010)$ guidance on assessment of capacity related issues in procurement advocates setting the tone for capacity assessment through a review of evidence in addition to stakeholder engagement to enable identification of an appropriate focus. To this end, the literature review providing the theoretical base of the study has explored areas relating to infrastructure provision and procurement. This has highlighted issues regarding the socio-economic significance of infrastructure, procurement capacity and procurement objectives.

It is well-established, based on studies in several domains (e.g. Tassabehji and Moorhouse, 2008; Smits et al., 2017; Devece et al., 2017; Mahamadu et al., 2018), that organisational capability or capacity has an impact on the fulfilment of a function or performance. For instance, studies conducted by Devece et al. (2017) on the outcome of information management capability on organisational performance, revealed a causal link between capability and three institutional performance measures competitiveness, customer fulfilment and productivity. Mahamadu et al. (2018) also found a causal link between building information modelling (BIM) capability of construction organisation and the success in delivering BIM. Similarly, Smits et al. (2017) reported a link between a component of BIM implementation capability and construction project performance.

Aligned to the foregoing discussion, procurement capacity of public agencies is thus similarly expected to have an impact on the attainment of infrastructure procurement objectives. However, what remains unclear, is the specific nature of this relationship, regarding an understanding of the degree to which components/elements of procurement capacity contribute to the attainment of infrastructure procurement objectives. In other words, it is unclear which components/elements of procurement capacity have the most impact in achieving specific procurement objectives. A useful step in closing this knowledge gap is to put forward a research framework that ties together the key concepts under investigation to drive the empirical phase of the study. Such a framework is proffered by Figure 1.

\section{[Insert Figure 1]}

The figure integrates in a unified and coherent manner the main facets of the knowledge gap (i.e. organisational procurement capacity and attainment of procurement objectives). Based on the literature discussed, the figure depicts examples of the constituent of organisational procurement capacity (see the left hand side of Figure 1) and examples of procurement objectives pertinent to the procurement 
of infrastructure (see the right hand side of Figure 1). Presented as part of the organisational procurement capacity are areas including: leadership; availability of policy, frameworks, rules and procedures for procurement; availability of financial resources for procurement; human resources management; and availability of material resources and infrastructure. The examples of procurement objectives pertinent to the procurement of infrastructure include: transparency; compliance; value for money; innovation; sustainability; accountability; promotion of equality, diversity and opportunity; and competition. The next section presents how the conceptual framework was operationalised.

\section{Research Methodology}

The research sought to investigate the extent of influence or impact of procurement capacity components/elements on the attainment of procurement objectives in the procurement of infrastructure. The study therefore adopted a quantitative research strategy (i.e. a survey) as the main strategy of inquiry in line with the conceptual framework. The quantitative approach was adopted due to its suitability for capturing and exploring relationships between factors (Yin, 2009). Other researchers have also adopted the survey strategy to investigate and assess procurement capacity issues (e.g. Basheka, 2010; Addo-Duah et al., 2014; Mahamadu et al. 2018; Manu et al., $2018,2019)$. The adoption of this strategy therefore ensured that the experience and views of the procurement respondents were adequately captured.

\section{Survey Design}

The study targeted personnel involved in procuring infrastructure in public institutions in Ghana and Nigeria. Three locales were targeted in Ghana (i.e. Ashanti, Greater Accra and Eastern Region) and two locales were targeted in Nigeria (Kaduna and Oyo State). The Greater Accra and Ashanti Regions were purposively selected because of their geopolitical significance. The Greater Accra region houses the capital city of Ghana, which is the largest city by population. The region is where all the various

8

government ministries and headquarters of quasi-government institutions are located and by extension it has a greater share of infrastructure procurement activities. The Ashanti Region was selected because it has the highest number of districts, and it is the home of the second largest city by population in Ghana. The Eastern region lies between the two regions and it, therefore, serves as an important link between the two largest cities.

Kaduna State and Oyo State were selected because they have key towns in Nigeria; Ibadan in Oyo State and Zaria and Kaduna in Kaduna State. Furthermore, government development plans (see Oyo State Government (2010) and Kaduna State Government (2013)) have revealed serious infrastructure shortfalls in Oyo and Kaduna state. The survey instrument was distributed to personnel engaged in procurement of infrastructure within the public sector in the two countries. The personnel were procurement professionals and staff within the built environment (e.g. architects, quantity surveyors, civil engineers and urban planners) who are engaged in the procurement of infrastructure.

The designed survey instrument sought data on the professionals' background, the adequacy of procurement capacity of their organisation, and the extent to which their organisation achieves procurement objectives in the procurement of infrastructure. The professionals' background, which was the first section of the questionnaire, captured data on their professional role, education, number of years worked within the current role, and number of years worked as an infrastructure procurement personnel. 
The second section of the questionnaire was dedicated to the professionals assessing the adequacy of organisational procurement capacity within their organisations. Drawing from the procurement capacity literature discussed above, particularly the organisational capacity facet (e.g. OECD and World Bank, 2004; UNDP, 2006; Geng and Doberstein, 2008; Aliza et al., 2011; Meyer, 2014) 23 organisational procurement capacity items were operationalized. The items are aligned to the areas of organisational procurement capacity of the Millennium Challenge Corporation's (MCC) procurement maturity model (Meyer, 2014) and capacity areas offered by OECD and World Bank, (2004) and UNDP (2006). The respondents indicated the adequacy of the 23 capacity items within their organisation using a five-point Likert scale ranging from 1 (very inadequate) to 5 (very adequate).

The last section of the questionnaire assessed the level of achievement of procurement objectives. Twelve procurement objectives (e.g. value-for-money, transparency, accountability, competition, innovation, fairness, promotion of equality and diversity, and sustainability) drawn from literature (e.g. Walker and Brammer, 2009; Ambe and Badenhorst-Weiss, 2012) were assessed. Similarly, a five-point Likert scale was used: $5=$ very high; $4=$ high; $3=$ moderate $; 2=$ low; $1=$ not at all.

The rate of response of a survey questionnaire is usually influenced by the layout and its physical attractiveness. Therefore, according to Asiedu and Alfen (2015), the organisation and language used in drafting the survey instrument should take into consideration the target respondents considering its general appeal and ease of reading. In a quantitative study, validity examines the extent to which a concept is accurately measured (Heale and Twycross, 2015). In the context of this study, ensuring validity was through pre-testing of the questionnaire to see if it covered the relevant domain related to the construct it was designed to measure. According to Gill

9

and Johnson (2010), pre-testing questionnaires is a significant step in survey because of the difficulty in knowing how respondents will interpret and respond to the questions. Based on these assertions, the designed questionnaire was pretested amongst public personnel involved in infrastructure procurement to ensure its suitability. In the two countries, questionnaires were hand delivered and collected in 2016/2017. Hand delivery and collection was used to ensure good response rate, as the postal system in both countries can be unreliable for a postal survey. Table 2 shows a summary of questionnaires distributed in each country and their respective response rate. Due to the non-availability of database of public agencies that procure infrastructure within these two countries of study it was difficult to obtain an appropriate sampling frame. Rowley (2014) advised that in such an instance it is appropriate to resort to a non probability sampling approach. Non-probability sampling allows for the determination of the sample size when there is no existing sampling frame and where they cannot be randomly selected (Rowley, 2014). The purposive sampling approach was therefore employed in this study. The purposive sampling technique was used to reach personnel in public agencies who are involved in the procurement of various types of infrastructure. In all, 853 questionnaires were administered to such personnel comprising of $480(56 \%)$ in Ghana and $373(43 \%)$ in Nigeria. Out of this, a total of 590 useable questionnaires (i.e. 69.17\%) were retrieved in Ghana ( $n=302 ; 62.92 \%$ ) and Nigeria $(n=288 ; 77.21 \%)$.

[Insert Table 2] 
exploratory factor analysis and multiple linear regression) were used to analyse the data. Exploratory factor analysis (EFA) was adopted because of its suitability for data reduction and extracting underlying components or dimensions of a construct/concept (Ahadzie et al., 2008; Field, 2013). EFA was used to extract the components of organisational procurement capacity. Multiple linear regression (MLR), due to its suitability for exploring relationships between variables, was used to interrogate the relationship between the components of organisational procurement capacity and the attainment of procurement objectives. The use of MLR enabled the determination of the contributions of the components to the attainment of procurement objectives.

\section{Results}

The results are separated into three sections. The first section presents descriptive statistics of the information on the respondents' demographics. In the second section, the results of the EFA of the organisational procurement capacity items are presented. The third section presents the results of the MLR.

Respondents' Demographic Information

Table 3 presents a summary of the respondent's demographic information.

[Insert Table 3]

The majority of the respondents were procurement officers $(35.1 \%)$, followed by engineers $(24.7 \%)$, quantity surveyors $(10.7 \%)$, administrators $(9.5 \%)$, purchasing

officers $(5.9 \%)$, architects $(5.4 \%)$, estate surveyors $(4.2 \%)$, builders $(4.1 \%)$, urban planners $(3.9 \%)$ and land surveyors (1.4\%). The rest of the respondents $(6.6 \%)$ include accountants, geologist, hydrologist, engineering technologist and environmental health officers. Most of the respondents $(66.9 \%)$ had acquired a minimum of bachelor's degree while $57.9 \%$ had over 5 years' experience in their professional role. The mean experience of the respondents in their professional role is $9.12(S D=7.29)$. Similarly, most of the respondents $(52.4 \%)$ have over 5 years' experience in infrastructure procurement with a mean of $6.62(S D=5.70)$. Overall, the respondents to the survey are sufficiently experienced in the procurement of infrastructure and therefore their responses can be deemed a credible representation of reality.

\section{Exploratory Factor Analysis}

The results of the EFA are shown in Table 4. EFA was adopted to uncover the interrelationships that exist among the variables (i.e. the capacity items) in order to find out which variables could be measuring aspects of the same phenomenon that were thought of as contributing to procurement capacity. EFA does not only present the choice of gaining a clear interpretation of the variables, but equally presents an opportunity to use the results in successive analyses (e.g. MLR) (Field, 2013).

However, there is still not a clear consensus amongst statisticians pertaining to the right sample size needed for factor analysis, which has led to the use of several rules of thumb (Field, 2013). For instance, Osborne and Costello (2004) recommend a sample size of at least 100 or five times the number of variables to be included in the principal component analysis. Meanwhile, according to Guadagnoli and Velicer (1988), irrespective of the conventional rules, the correlation between sample size and number of variables is not a significant reason for ascertaining stability but rather component saturation and absolute sample size. On the contrary, Field (2013) suggest that the absolute sample size is not the only variable to consider in ascertaining the suitability for factor solution but the absolute size of the factor loadings. Notwithstanding the several arguments on the suitability of a sample size, the EFA conducted reveals the 
sample size was favourable. With a sample response of 590 , the results showed the average communality of the variables after extraction was more than 0.5 .

Additionally, the results of the Kaizer-Meyer-Olkin (KMO) which is used to determine the suitability of sample size recorded a high value of 0.95 while the results of the Bartlett test were significant. Hence, the essential checks for factor analysis to determine the sufficiency of the sample size were favourable. Two stages (i.e. factor extraction using principal component analysis; and factor rotation using varimax rotation) were adopted for the factor analysis. The eigenvalue was set at 1.0 while the factor loading was set at 0.5 resulting in the extraction of three components. The variances explained by each of the components is as follows: Component $1=51.377 \%$; Component $2=7.255 \%$; and Component $3=5.071 \%$; which accumulatively accounts for $63.7 \%$ of organisational procurement capacity.

Critical assessment of the latent correlations amongst the variables under each component suggest the following explanation to each component: Component 1 Management of the procurement process; Component 2 - Human and physical resources; and Component 3 - Financial resources and management.

\section{[Insert Table 4]}

\section{Multiple Linear Regression}

The factors scores (from the EFA) for the three components of organisational procurement capacity (management of the procurement process, human physical resources, and financial resources and management) were further regressed, using MLR, against the 12 procurement objectives. Table 5 shows the regression results for the relationship between organisational procurement capacity and the procurement objectives. The Durbin-Watson test results all fell within 1.50 and 2.50, which shows the residual errors are not correlated (Field, 2013). Additionally, the regression equations were all significant at $\mathrm{p}<0.001$, while the coefficients were all significant at $\mathrm{p}<0.001$. Results of the adjusted $\mathrm{R}^{2}$ suggest 'management of the procurement process', 'human and physical resources' and 'financial resources and management' explain 28.0\%, 29.4\%, 27.2\%, 30.2\%, 25.4\%, 30.9\%, 35.6\%, 31.4\%, 31.5\%, 33.7\%, $28.4 \%$ and $30.7 \%$ of the variance in transparency; compliance; value-for-money; promotion of equality, diversity and opportunity; private sector participation; innovation; sustainability; accountability; standardization of procurement procedures; competition in procurement process; cost effectiveness; and professionalism; respectively. The regression reveals that all three components of organisational procurement capacity are significantly and positively related to the attainment of all the 12 procurement objectives studied. However, the contributions of the three components (indicated by the $b$-values) to the attainment of the objectives vary. 'Management of the procurement process', 'human and physical resources' and 'financial resources and management' are the greatest contributors to the attainment of seven, one and four procurement objectives, respectively.

In all, 'management of procurement process' (which encapsulates policy and legal framework, public engagement, mutual accountability mechanisms and leadership) is the most important contributor to the attainment of procurement objectives. 


\section{Discussion}

The EFA revealed a clustering of the procurement capacity items into three components (i.e. 'management of the procurement process', 'human and physical resources' and 'financial resources and management') contrary to the eight organisational procurement capacity areas by UNDP (2006). In discussing the results much effort was given to the pattern-matching instead of discussing the individual items under each main component. This thread became necessary because of the need to avoid the repetition of issues that have already been presented and discussed in the conceptual underpinning of this study.

The component, 'management of the procurement process', which is explained by seven variables/capacity items, is observed to be the most significant organisation procurement capacity component, accounting for $51.377 \%$ of the variance in

organisational procurement capacity. The seven variables identified under this component are: internal mechanisms that ensure conformance to national policy and legal frameworks for procurement; internal anti-corruption mechanisms; vision and strategic planning for procurement; effective procurement auditing procedures; dialogue with civil society and stakeholders; application of sanctions for non compliance; leadership and top management support for procurement; inclusion and participation of civil society organisations and media in the public procurement process; and inclusion and participation of private sector institutions in procurement process.

The procurement process comprises all activities throughout the project, starting from establishing the client's aspirations and business case through to checking the compliance of the previous requirements (Alencastro et al., 2017). Managing the procurement process therefore implies managing all the activities throughout the project. The BS 8534 (2011) which deals with construction policies, strategies and procedures divides the procurement process into four key parts namely: initiation, procurement strategy, procurement tactics, and managing performance and delivery. Within the initiation phase, the business case is developed, and project objectives, aspirations and needs are further identified (Alencastro et al., 2017). Within the strategic phase, the initial conceptualisation of the project is translated into objective information through the client brief. This will then be followed by an assessment of the procurement method as well as the planning of the appropriate strategy (BS 8534, 2011). During the procurement tactics phase, all supporting activities are defined in order to monitor and make accountable the project performance (Alencastro et al., 2017). In the final phase, which is the management of performance and delivery, the project goals developed in the earlier phases are linked to the specific project outcomes in the design, construction and operation phases of the project (Alencastro et al., 2017).

It is worth noting that operating within these four phases involve the use of resources. However, the resources are more likely to be misappropriated in less formalised public organisations. The poor management of resources affects procuring entities in achieving their intended objectives (Changalima et al., 2020). Since the fundamental principles of a worthy procurement practice include accountability and consistency, which requires entities to engage contractors competitively through a fair process unless prevailing conditions require otherwise (Kakwezi and Nyeko, 2019), the absence of an internal mechanism that ensures conformance to national policy and legal frameworks for procurement may lead to corrective instead of preventive actions. Though there exist mixed reactions concerning the contributions of some of the variables identified in Component 1 towards the effective and efficient management of the procurement process, all the seven variables identified under this component 
stress the need to properly manage the procurement process as efficiently and effectively as possible. The onus lies with various organisations to strive to properly manage the procurement process through the identification of the needed opportunities when they arise, and properly managing the internal operations. Guarnieri and Gomes (2019) iterated that in managing the procurement process, there is always the tendency of the procurement function to move towards a strategic role within an organisation. There is therefore the need for public procurement entities to ensure that the mindsets of procurement practitioners are directed towards the

strategic perspective of the procurement function (Changalima et al., 2020). In the view of Mrope (2018), this strategic role of procurement can only be attained when it is inculcated in the corporate strategic planning process and implementation at the same level as the other functional areas.

Component 2 (i.e. human and physical resources) from Table 3 extracted seven variables: highly motivated and satisfied procurement staff; physical and logistical resources that support procurement (e.g. means of transport, office space etc.); well remunerated/compensated procurement staff; training and effective procurement personnel capacity development; computing and ICT facilities; effective human resource management of procurement staff; and number of qualified procurement personnel. These variables together account for $7.255 \%$ of organisational procurement capacity.

The human resource refers to the people whose knowledge, skills and abilities are utilised to create and deliver the product and service (Guests, 2019). This resource is considered as any organisation's greatest asset because an organisation cannot be properly managed or create and deliver products and services without using the knowledge, skills and abilities of its workforce (Guests, 2019). This implies that for any procurement authority to be on top of its activities it must pay attention to its human resources. A proficient procurement staff is therefore considered one of the pillars of the basis for procurement reforms and mainstreaming (Adjei-Bamfo and Maloreh Nyamekye, 2019), which directly has an impact on professionalism. Just as the human resource strategic plan of an entity will seek to attract the right types and number of people, develop the knowledge, skills and abilities of employees, and retain the employees within the entity (Guests, 2019), successful procurement entities pay particular attention to its procurement staff. Since procurement staff can be confronted with various issues including the absence of data about the procurement processes, and principles and legal frameworks, there is the need to for procurement entities to spend adequate time in training its human resource to ensure compliance with procurement rules. As extracted in Component 2, where qualified procurement staff are employed, highly motivated and satisfied, well remunerated/compensated, and well trained to improve their capacity, there is the tendency for the human resource to function very well to help the entity achieve its objectives.

The physical resources on the other hand refers to the tools or objects required by an organisation to deliver its products or services (Guests, 2019). Such resources may include tangible items that are necessary and available for a business to function. In the view of Cutrina (2020), physical resources are all the tangible resources owned and used by a company such as land, manufacturing equipment, office equipment, information technology and its attendant equipment, and the likes. Procurement entities need some physical resources to be able to function effectively and efficiently (Manu et al., 2019; Yevu and Yu, 2019). The variables that fell under physical resources in Component 2 include physical and logistical resources that support procurement (e.g., means of transport, office space etc.) and computing and ICT 
facilities. In a typical procurement entity, the onus always lies with management to identify the appropriate physical resources needed to achieve their objectives. In this case, the entity must have a physical resource plan that identifies how to obtain the

needed resources, maintain those resources, and acquire new resources when the need arises.

The component 'financial resources and management' extracted six variables: procurement rules and procedures that incorporate lifecycle approach to analysis and costing; capacity to self-finance projects (e.g. internally generated funds or public/private partnerships); integration of procurement with internal financial management and budgeting systems; capacity to meet project payment obligations on time; capacity for long term planning and allocation of funds for procurement; and existence of policies aimed at promoting social or environmentally responsible procurement. These collectively explain $5.071 \%$ of organisational procurement capacity.

Financial resource refers to the money or capital used to fund an organisation's activities. In the broad sense, this resource may include the money that is generated by sales, loans, grants or donations (Guests, 2019). Finance plays a key role in procurement so it is important to understand the value it offers. Procurement activities consume monetary resources of an organisation which has to be budgeted in advance to prepare realistic cost estimations. This notwithstanding, Changalima et al. (2020) report that in practical sense there are procurement undertakings conducted without appropriate budgeting. Since unrealistic budgets affect the conduct of procurement activities (Agwot, 2016), procurement entities must ensure that what has been budget for truly reflect the estimated cost of procuring the items from the market. This will in the long-term help in achieving value for money (VfM). VfM is the balance between performance and price that offers the highest total benefit for a selection criterion (Asare and Prempeh, 2016). The use of the VfM principle in the procurement process therefore ensures the selection of the tender that gives the best set of factors comprising life-cycle cost, service, quality, and other factors in order to meet the required needs. However, accepting the lowest price tender can have negative ramifications with implications for the achievement of social objectives. Very low tender prices are likely to push the successful tenderer to cut costs, by taking shortcuts that can affect the quality of the product. From the findings of this study, it is evident that implementing procurement rules and procedures that incorporate lifecycle approach to analysis and costing, entities building their capacity to self-finance projects, integrating procurement with internal financial management and budgeting systems, meeting project payment obligations on time, long term planning and allocation of funds for procurement, putting in place policies aimed at promoting social or environmentally responsible procurement are all ways that can help improve and manage an entity's financial resources.

From the foregoing, it is not surprising from the results of the MLR that component 1 (i.e. management of the procurement process) has the greatest impact on the attainment of seven out of the 10 procurement objectives. In countries where the principle of equity, fairness and transparency has been the key political concern, the 
use of a regulatory framework to manage public procurement has been the status quo

15

(Fourie and Malan, 2020). This arrangement echoes a conventional attitude to public procurement by depending on regulation as the fundamental way of checking management process and implementation of policy. The effect of management of the procurement process on accountability is also consistent with the findings of the Economic Commission for Africa (2003), which observes an improved public administration which stresses on openness and accountability to the needs of customers is considered a good governance practice. This is the reason why steps taken to guarantee accountability are important in decentralized governance systems

(Taamneh et al., 2020). The strong effect of the procurement management process on compliance is also consistent with studies which argue that compliance can be achieved through clearer rules, more supplier awareness and effective enforcement of procurement rules (Asare and Prempeh, 2016; Rahmani et al., 2017; Loader, 2018; Larbi et al., 2019).

From the MLR, the need for financial resources towards the attainment of procurement objectives cannot be overemphasised, especially as component 3 (i.e. financial resources and management) is the next strongest contributor to four out of the 12 objectives analysed. For instance, the need for financial resources and management is a fundamental requirement in seeking private sector participation in the provision of public infrastructure towards achievement of VfM. Private sector participation offers the possibility of offering the services required by the public in a manner that can

provide VfM (Walker and Brammer, 2009). This is because private sector participation can offer scope for innovation in how services are delivered, and better management of project and the resulting asset. Given the significance of public procurement, there should be adequate financial resources and their management to realise the triple constraint of economic (cost effectiveness), environmental and social success. At the tendering stage, the interest of public authorities should lie with stimulating suppliers' offers, while seeking to select the lowest evaluated responsive tender that meets social and environmental considerations (Rahmani et al., 2017).

From the regression analysis, component 2 (i.e. human and physical resources) was also identified to contribute to attaining all the procurement objectives. In recent times, the worlds of human resources and procurement have increasingly become entwined. The traditional procurement organisation has now evolved into a sourcing and procurement services organisation with more strategic function of procurement closely working with the human resource management. There is therefore the need to enhance the human resource of procurement teams to unlock their ability to achieve procurement objectives. The human resource capacity boosters for procurement personnel can be in the form of highly motivating the staff, remunerating, and compensating them well, training them well to progress in their careers, among other things. Basically, physical resources are in the form of material resource and infrastructure. According to Li (2014), logistics and communication are two of such physical resources which often impact procurement activities. Within the context of this study, component 2 revealed that the physical resources which when put in place has the ability to affect achievement of procurement objectives are in the form of logistics (i.e. means of transport, office space, etc.), and computing and ICT facilities. These facilities, especially, the computing and ICT have the potential to improve the capacity of the human resource to help achieve the procurement objectives of a given organisation. Though component 2 contributes to the attainment of all the procurement objectives, the MLR shows that it is the greatest contributor to the achievement of value 
for money (VfM). Well qualified and highly motivated procurement personnel within any public organisation is therefore needed to identify and remove waste in the procurement process, and, above all, enhance VfM.

\section{Conclusions}

The research investigated the effect of procurement capacity on the attainment of procurement objectives. The study has empirically demonstrated that the attainment of infrastructure procurement objectives is inextricably connected to the adequacy of organisational procurement capacity of public procurement entities. The findings from the study suggest that the organisational procurement capacity comprises of three components: management of the procurement process; human and physical resources; and financial resources and management. The findings further showed the impact of various components of the organisational procurement capacity on the attainment of procurement objectives. In this regard, 'management of the procurement process', which encapsulates procurement capacity items, such as conformance to policy and legal frameworks for procurement and anti-corruption, has the greatest contribution to the attainment of procurement objectives in the procurement of infrastructure. Significant investments and commitments are therefore needed to strengthen the management of the procurement process in the procurement of infrastructure.

Overall, the outcome of the above study has provided robust and unique insights on how specific procurement objectives are affected by organisational procurement capacity. The implications of the findings are evident for the procurement agencies within the two countries of study as well as other developing countries with procurement settings like those studied in this paper. The implications are in two-folds, i.e. to policy makers and to public procurement agencies. The findings could inform policy makers at various levels of public institutions to formulate, resource, and implement capacity-building development plans that have appropriate development priorities based on the relative contributions of procurement capacity components to the attainment of the desired procurement objectives. Aligned to this, multilateral organisations that fund infrastructure and procurement reforms in various countries could consider prioritising investment into the development of specific capacity components that contribute the most to the attainment of desired procurement objectives. Also, to public agencies involved in infrastructure procurement, this study provides a strong justification for investment into developing their procurement capacity. This finding provides an important justification for the need for continued investment in building the capacity of such agencies to ensure and enhance sustained attainment of procurement objectives.

While the findings of this study provide some useful inferences, key limitations are acknowledged. The study adopted a quantitative survey of procurement personnel from various public institutions. The underlying explanations regarding the effects of the observed procurement capacity on the attainment of procurement objectives could, therefore, not be explored deeper. In view of this, further studies could be conducted using qualitative approaches to unearth further empirical realities.

References

Addo-Duah, P., Westcott, T., Mason, J., Booth, C.A, and Mahamadu, A. M. (2014), "Developing capability of public sector procurement in Ghana: An assessment of 
the road subsector client", In: Proceedings of Construction Research Congress 2014, 19-21 May 2014, Atlanta, Georgia, USA. American Society of Civil Engineers.

Adewole, A. (2014), "Governance reform and the challenge of implementing public procurement law regime across Nigerian state and local governments", International Journal of Public Administration and Management Research (IJPAMR), Vol. 2 N. 4, pp. 25-32.

Adjei-Bamfo, P. and Maloreh-Nyamekye, T. (2019), "The "baby steps" in mainstreaming sustainable public procurement in Ghana: A "double-agency" perspective", Journal of Public Affairs, Vol. 19(2019), pp. 1-16.

AfDB (2013), The Infrastructure action plan for Nigeria: closing the Infrastructure gap and accelerating economic transformation: summary report. Tunis: AfDB.

Available at: https://www.afdb.org/fileadmin/uploads/afdb/Documents/Project and-Operations/An_Infrastructure_Action_Plan_for_Nigeria_-

_Closing_the_Infrastructure_Gap_and_Accelerating_Economic_Transformatio n .pdf (accessed 01/03/2016).

Agwot, K.R. (2016), "Public procurement in developing countries: Objectives, principles and required professional skills", Public Policy and Administration, Vol. 6 No. 8, pp. 20-29.

Ahadzie, D. K., Proverbs, D. G. and Olomolaiye, P.O. (2008), "Critical success criteria for mass house building projects in developing countries", International Journal of Project Management, Vol. 26 No. 6, pp. 675-687.

Alencastro, J., Fuertes, A. and de Wilde, P. (2017), "Delivering energy-efficient social housing: Implications of the procurement process", Procedia Engineering, Vol. 182(2017), pp. 10-17.

Aliza, A. H., Stephen, K. and Bambang, T. (2011), "The importance of project governance framework in project procurement planning", Procedia Engineering, Vol. 14 (2011), pp. 1929-1937.

Ambe, I. M. and Badenhorst-Weiss, J. A. (2012), "Procurement challenges in the South African public sector", Journal of transport and supply chain management, Vol. 6 No. 1, pp. 242-261.

Anvuur, A., Kumaraswamy, M. and Male, S. (2006), "Taking forward public procurement reforms in Ghana", In Proceedings of the 2006 CIB W107: Construction in Developing Countries International Symposium: Construction in Developing Economies: New Issues and Challenges. CIB.

Asare, E.N. and Prempeh, K.B. (2016), "Measures of ensuring value for money in public procurement: A case of selected Polytechnics in Ghana", Journal of Logistics Management, Vol. 5 No. 1, pp. 22-31.

Aschauer, D. A. (1989), "Is public expenditure productive?", Journal of monetary economics, Vol. 23 No. 2, pp. 177-200.

Asiedu, R. O. and Alfen, H. W. (2014), "Factors engendering cost misrepresentation of public sector projects in Ghana", International Journal of Sustainable Construction Engineering and Technology, Vol. 5 No. 2, pp. 13-24.

Asiedu, R. O. and Alfen, H. W. (2015), "Assessing the frequency of factors engendering cost overruns using frequency indices and factor analysis for public building projects in Ghana", Journal of International Real Estate and Construction Studies, Vol. 3 No. 2, pp. 1-22.

Awuzie, B.O. and McDermott, P. (2016), "The role of contracting strategies in social value implementation", Procurement and Law, Vol. 169 No. 3, pp. 106-114 Basheka, B. C. (2010), Public procurement skills requirement framework for local government systems in Uganda: perceptions from professionals. IPPU. Available online at http://www. ippu.or.ug (accessed 01/03/2016).

Bolton, P. (2006), "Government procurement as a policy tool in South Africa", Journal 
of Public Procurement, Vol. 6 No. 3, pp. 193-217.

BS 8534:2011. Construction procurement policies, strategies and procedures

- Code of practice. BSI; 2011

Cadot, O., Röller, L. H. and Stephan, A. (2006), "Contribution to productivity or pork barrel? The two faces of infrastructure investment", Journal of public Economics, Vol. 90 No. 6-7, pp. 1133-1153.

Calderón, C. and Servén, L. (2008), Infrastructure and economic development in sub

Saharan Africa, Development Research Group Macroeconomics and Growth Team,

Policy Research Working Paper 4712. Washington, DC: World Bank.

Calderón, C. and Servén, L. (2014), Infrastructure, growth, and inequality: An overview. The World Bank.

Changalima, I.A., Mushi, G.O. and Mwaiseje, S.S. (2020), Procurement planning as a strategic tool for public procurement effectiveness: Experiences from selected public procuring entities in Dodoma city, Tanzania. Journal of Public Procurement. Available at: https://www.emerald.com/insight/1535-0118.htm, (accessed 12 December 2020).

Cutrina, A. (2020), How physical resources are controlled in an organisation. Available at: https://askinglot.com/how-physical-resources-are-controlled-in-an organisation (accessed 12 December 2020).

de Mariz, C. L., Ménard, C. and Abeillé, B. (2014), Public procurement reforms in Africa: Challenges in institutions and governance. Oxford University Press, USA. Devece, C., Palacios, D. and Martinez-Simarro, D. (2017), "Effect of information management capability on organizational performance", Service Business, Vol. 11 No. 3, pp. 563-580.

Economic Commission of Africa (2003), Public Sector Management Reforms in Africa. Addis Ababa: Economic Commission of Africa.

Evenett, S. J. and Hoekman, B. M. (2005), International Cooperation and the Reform of Public Procurement Policies. World Bank Policy Research Working Paper 3720. Washington, DC: World Bank.

Field, A. P. (2013), Discovering statistics using IBM SPSS statistic, $4^{\text {th }}$ edition: Sage Publications: Thousand Oaks, California.

Fourie, D. and Malan, C. (2020), "Public procurement in the South African economy: Addressing the systemic issues" Sustainability, Vol. 12(2020), pp. 1-23.

Gebregziabher, G., Namara, R. E. and Holden, S. (2009), "Poverty reduction with irrigation investment: An empirical case study from Tigray, Ethiopia" Agricultural Water Management, Vol. 96 No. 12, pp. 1837-1843.

Geng, Y. and Doberstein, B. (2008), "Greening government procurement in developing countries: Building capacity in China", Journal of environmental management, Vol. 88 No. 4, pp. 932-938.

Gill, J. and Johnson, P. (2002), Research methods for managers. Sage. Global Construction Perspectives and Oxford Economics, O. (2013), Global Construction 2025. A global forecast for the construction industry to 2025. Global Construction Perspectives and Oxford Economics.

Guadagnoli, E. and Velicer, W. F. (1988), "Relation of sample size to the stability of component patterns", Psychological bulletin, Vol. 103 No. 2, pp. 265-275. Guanieri, P. and Gomes, R.C. (2019), "Can public procurement be strategic? A future agenda proposition", Journal of Public Procurement, Vol. 19 No. 4, pp. 295-321. Guests (2019), The link between strategic planning and human resource planning. Available at: https://blogs.hrminfo.eu/2019/07/11/the-link-between-strategic planning-andhuman-resource-planning/(accessed 14 December 2020). Heale, R. and Twycross, A. (2015), "Validity and reliability in quantitative studies", Evidence Based Nursing, Vol. 18 No. 3, pp. 66-67. 
International Trade Centre, ITC, (2014), Empowering women through public procurement. Available at: http://www.intracen.org, (accessed 7 September 2020).

Jensen, E. R. K. (2009), Procurement capacity development and its integration in a broader public administration reform: New thinking, lessons learned from innovative programmes and their potential for the strengthening of public procurement systems. Presentation delivered at the ADB High Level Forum on Public Procurement Reforms in Africa, 16-17 Nov. 2009, Tunis. UN Procurement Capacity Development

Centre.

Available

http://unpcdc.org/media/132292/adb\%20speach.pdf (accessed 01/03/2016).

Jones, D.S. (2002), "Procurement practices in the Singapore civil service: Balancing control and delegation", Journal of Public Procurement, Vol. 2 No. 1, pp. 29-53.

Jones, D.S. (2007), "Public Procurement in Southeast Asia: Challenge and Reform", Journal of Public Procurement, Vol. 7 No. 1, pp. 3-33.

Kaduna State Government (2013), State development plan 2014-2018. Kaduna:

Kaduna State Government. Available online at http://www.sparc

nigeria.com/RC/files/1.1.9_Kaduna_Development_Plan_2014_2018.pdf. (accessed 05/10/2016).

Kakwezi, P. and Nyeko, S. (2019), "Procurement processes and performance: efficiency and effectiveness of the procurement function", International Journal of Social Sciences Management and Entrepreneurship, Vol. 3 No. 1, pp. 172-182.

Kwak, Y. H., Chih, Y. and Ibbs, C. W. (2009), "Towards a comprehensive understanding of public private partnerships for infrastructure development", California management review, Vol. 51 No. 2, pp. 51-78.

Lakshmanan, T. R. (2011), "The broader economic consequences of transport infrastructure investments", Journal of Transport Geography, Vol. 19 No. 1, pp. $1-12$.

Larbi, B.O, Baiden, B.K. and Agyekum, K. (2016), "Compliance with transparency provisions in the Public Procurement Act, 2003 (ACT 663)", International Journal of Procurement Management, Vol. 12 No. 1, pp. 112-133.

Laryea, S., Alkizim, A. and Ndlovu, T. (2013), "The increasing development of publication on sustainable procurement and issues in practice", In: Smith, S.D and Ahiaga-Dagbui, D.D (Eds) Procs 29th Annual ARCOM Conference, 2-4 September 2013, Reading, UK, Association of Researchers in Construction Management.

Lewis-Faupel, S., Neggers, Y., Olken, B. A. and Pande, R. (2016), "Can Electronic Procurement Improve Infrastructure Provision? Evidence from Public Works in India and Indonesia", American Economic Journal: Economic Policy, Vol. 8 No. 3, pp. 258-83.

$\mathrm{Li}, \mathrm{X}$. (2014), "Operations management of logistics and supply chain: Issues and directions", Discrete Dynamics in nature and Society, 2014, pp. 1-7.

Loader, K. (2018), "Small-and medium-sized enterprises and public procurement: A review of the UK coalition government's policies and their impact", Environment and Planning C: Politics and Space, Vol. 36 No. 1, pp. 47-66.

Locatelli, G., Mariani, G., Sainati, T. and Greco, M. (2017), "Corruption in public projects and megaprojects: There is an elephant in the room!", International Journal of Project Management, Vol. 35 No. 3, pp. 252-268.

McCarthy, J. (2006), "All aboard the infrastructure train: European infrastructure assets are ideal to be included in pension portfolios, But what are the differing products in the market and what characteristics should investors look for?", Professional Investor, Vol. 16 No. 5, p. 10.

Mensah, S. and Ameyaw, C. (2012), "Sustainable procurement: the challenges of practice in the Ghanaian construction industry", In: West Africa Built Environment 
Research (WABER) Conference 24-26 July 2012 Abuja, Nigeria. WABER.

Meyer, J. (2014), Institutional maturity model: A tool to fill gaps in measuring development of procurement systems (presentation). The World Bank Conference on Procurement: Delivering Development Outcomes, February 19, 2014, Washington, D.C. Available at http://www.worldbank.org/content/dam/Worldbank/Event/Meyer.pdf (accessed 01/03/2016).

Mahamadu, A. M., Manu, P., Booth, C., Olomolaiye, P., Coker, A., Ibrahim, A. and Lamond, J. (2018), "Infrastructure procurement skills gap amongst procurement personnel in Nigeria's public sector", Journal of Engineering, Design and Technology, Vol. 16 No. 1, pp. 2-24.

Manu, P., Mahamadu, A-M., Booth, C., Olomolaiye, P., Ibrahim, A. D. and Coker, A. (2019), "Infrastructure procurement capacity gaps in Nigeria public sector institutions", Engineering, Construction and Architectural Management. DOI: 10.1108/ECAM-11-2017-0240

Manu, P., Mahamadu, A. M., Booth, C., Olomolaiye, P., Ibrahim, A. D. and Coker, A. (2018), "Assessment of procurement capacity challenges inhibiting public infrastructure procurement: A Nigerian inquiry", Built Environment Project and Asset Management, Vol. 8 No. 4, pp. 386-402.

Mrope, N.P. (2018), Determinants of performance of procurement departments in public entities in Tanzania. Jomo Kenyatta University of Agriculture and Technology, Kenya.

Ndou, V. (2004), "E-Government for developing countries: opportunities and challenges", The Electronic Journal of Information Systems in Developing Countries, Vol. 18 No. 1, pp. 1-24.

Newell, G., Chau, K.W. and Wong, S.K. (2009), "The significance and performance of infrastructure in China", Journal of Property Investment and Finance, Vol. 27 No. 2, pp. 180-202.

OECD (2002), The relationship between regional trading agreements and the multilateral trading system. Government Procurement." 9 October 2002. OECD and World Bank (2004), Good practice paper on procurement capacity development. The OECD Development Assistance Committee (DAC) - World Bank 3rd joint round table on strengthening procurement capacities in 24 developing countries, 30 November 2 December 2004, Johannesburg. OECD and World Bank.

Offei, I., Kissi, E. and Badu, E. (2016), "Public procurement policies and strategies for capacity building of SME construction firms in Ghana", International Journal of Procurement Management, Vol. 9 No. 4, pp. 455-472.

OGC (2007), Sustainability: Achieving Excellence in Construction Procurement Guide 11. London: HM Treasury.

Okunlola Ojo, S., Aina, O. and Yakeen Adeyemi, A. (2011), "A comparative analysis of the performance of traditional contracting and design-build procurements on client objectives in Nigeria", Journal of Civil Engineering and Management, Vol. 17 No. 2, pp. 227-233.

Osborne, J.W. and Costello, A.B. (2014), "Sample size and subject to item ratio in principal component analysis", Practical Assessment, Research and Evaluation, Vol. 9 No. 11, pp. 1-9.

Owusu, E.K., Chan, A.P. and Ameyaw, E. (2019), "Toward a cleaner project procurement: Evaluation of construction projects' vulnerability to corruption in developing countries", Journal of Cleaner Production, Vol. 216, pp.394-407.

Oxford Economics (2017), Global infrastructure outlook - infrastructure investment need, 50 countries, 7 sectors to 2040. Sydney: Global Infrastructure Hub. Available online at: https://outlook.gihub.org/ (accessed 28/01/2019).

Oyo State Government (2010), Strategic health development plan (2010-2015). 
Ibadan: Oyo State Government. Available online at

http://www.mamaye.org.ng/sites/default/files/evidence/Oyo\%20SSHDP\%2005.0

1.11.pdf (accessed 28/01/2017).

Parente, S. and Prescott, E. C. (2000), Barriers to Riches Cambridge. MA: MIT. Qiao, Y. and Cummings, G. (2003), "The use of qualifications-based selection in public procurement: a survey research", Journal of Public Procurement, Vol. 3 No. 2, pp. 215-249.

Rahmani, F., Maqsood, T. and Khalfan, M. (2017), "An overview of construction procurement methods in Australia", Engineering, Construction and Architectural Management, Vol. 24 No. 4, pp. 593-609.

Raymond, J. (2008), "Benchmarking in public procurement", Benchmarking: An International Journal, Vol. 15 No. 6, pp. 782-793.

Rioja, F. K. (1999), "Productiveness and welfare implications of public infrastructure: a dynamic two-sector general equilibrium analysis", Journal of Development Economics, Vol. 58 No. 2, pp. 387-404.

Rothery, R. (2003), "China's legal framework for public procurement", Journal of Public Procurement, Vol. 3 No. 3, pp. 370-388.

Rowley, J. (2014), "Designing and using research questionnaire" Management Research Review, Vol. 37 No. 3, pp. 308-330.

Sahoo, P. and Dash, R. K. (2009), "Infrastructure development and economic growth in India", Journal of the Asia Pacific economy, Vol. 14 No. 4, pp. 351-365. Saunders, M., Lewis, P. and Thornhill, A. (2007), Research Methods for Business Students, 4th ed. Essex: Pearson Education Ltd.

Smits, W., van Buiten, M. and Hartmann, T. (2017), "Yield-to-BIM: impacts of BIM maturity on project performance", Building Research and Information, Vol. 45 No. 3, pp. 336-346.

Taamneh, M., Rawabdeh, M.A. and Abu-Hummour, A.M (2020), "Evaluation of decentralisation experience through administrative, and fiscal indicators: The case of Jordan", Journal of Public Affairs, 20(2020), pp. 1-17.

Tassabehji, R. and Moorhouse, A. (2008), "The changing role of procurement: Developing professional effectiveness", Journal of Purchasing and Supply Management, Vol. 14 No. 1, pp. 55-68.

The Economist Intelligence Unit Limited, EIUI, (2009), The critical role of infrastructure for the sustainable development goals. Available at:

https://content.unops.org/publications/The-critical-role-of-infrastructure-for-the

SDGs_EN.pdf?mtime=20190314130614, (accessed 1 September 2020)

UNDP (2006) Procurement Capacity Assessment User's Guide. New York, NY:

UNDP. UNDP (2007) Capacity Assessment Practice Note. UNDP. Available online at http://www.unpcdc.org/media/8651/pn_capacity_development.pdf (accessed 01/03/2016).

UNDP (2010) Public procurement capacity development guide. New York, NY: UNDP. Available online at from:

http://unpcdc.org/media/140954/procurement\%20capacity\%20assessment\%20 guide.pdf (accessed 01/03/2016).

United Nations Economic and Social Council (2016) Progress towards the Sustainable Development Goals - Report of the Secretary-General. United Nations Economic and Social Council. Available at: https://unstats.un.org/sdgs/files/report/2016/secretary-general-sdg-report-2016EN.pdf (accessed 23/03/2017).

Van de Walle, D. (2009), "Impact evaluation of rural road projects", Journal of Development Effectiveness, Vol. 1 No. 1, pp. 15-36. 
Walker, H. and Brammer, S. (2009), "Sustainable procurement in the United Kingdom public sector", Supply Chain Management: An International Journal, Vol. 14 No. 2, pp. 128-137.

World Bank (1994), World Development Report: Infrastructure for Development. Washington, DC: The World Bank.

World Bank (1995), Restoring urban Nigeria a strategy for restoring urban infrastructure and services in Nigeria. Report No. 45557. Washington, DC: World Bank. Available at http://documents.worldbank.org/curated/en/1995/12/10735837/restoring-urban nigeria-strategy-restoring-urbaninfrastructure-services-nigeria (accessed 01/03/2016).

World Bank (2000), Nigeria: Country Procurement Assessment Report (CPAR), Vol 1. Summary of findings and recommendations. Washington, DC: World Bank. Available at: http://documents.worldbank.org/curated/en/2000/06/1121258/nigeria countryprocurement-assessment-report-cpar (accessed 01/03/2016).

World Bank (2003), Ghana: Country Procurement Assessment Report (CPAR), Vol 1. Executive Summary. Washington, DC: World Bank. Available at https://openknowledge.worldbank.org/handle/10986/15638 Accessed 01/03/2016).

Wright, T. (2015), “New development: Can 'social value' requirements on public authorities be used in procurement to increase women's participation in the UK construction industry?", Public Money and Management, Vol. 35 No. 2, pp.135140.

Yevu, S.K. and Yu, A.T.W. (2019), "The ecosystem of drivers for electronic procurement adoption for construction project procurement: A systematic review and future research directions", Engineering, Construction and Architectural Management, Vol. 27 No. 2, pp. 411-440.

Yin, R.K. (2009), Case Study Research: Design and Methods, 4th ed. Sage Publications: Thousand Oaks, California

resources for procurement .

Human resources

management

- Availability of material

resources and infrastructure 
- Compliance

- Value for Money

- Innovation

- Sustainability
- Accountability

- Promotion of equality, diversity and opportunity Competition

Figure 1: Conceptual framework of the relationship between organisational procurement capacity and attainment of procurement objectives

Table 1: Core Areas of Organisational Procurement Capacity (UNDP,

2006) Core Areas Description

Leadership Strategic direction, improved understanding and relationships, and greater collective effectiveness in procurement

Policy framework Provision of framework, adherence to rules and practices within which competition is maximized

Mutual accountability mechanisms Practices that enhance efficient, responsive, transparent and accountable public administration

Public engagement Engaging the private sector, individuals, civil society organisations, and media in public procurement

Human resources Exercising capacity is made up of proportionate resource endowment and human capacity development

Financial resource Financial efficiency and capacity to manage public procurement is within budget and fiscal constraints

Physical resources Availability of material resources and infrastructure Environmental resources 
Application of environmentally sustainable and socially inclusive principles

Table 2: Response Rate

Country Response rate

\begin{tabular}{|l|c|c|}
\hline Locations & $\begin{array}{l}\text { Questionnaire } \\
\text { administered }\end{array}$ & $\begin{array}{l}\text { Useable } \\
\text { questionnaire } \\
\text { received }\end{array}$ \\
\hline $\begin{array}{l}\text { Ashanti, Eastern } \\
\text { and Greater } \\
\text { Accra Region }\end{array}$ & 480 & 302 \\
\hline $\begin{array}{l}\text { Oyo State and } \\
\text { Kaduna State }\end{array}$ & 373 & 288 \\
\hline & 853 & 590 \\
\hline
\end{tabular}


Nigeria $77.21 \%$ Combined $69.17 \%$

Table 3: Demographic Information of the Respondents 


\begin{tabular}{|c|}
\hline 139 \\
146 \\
63 \\
35 \\
32 \\
8 \\
56 \\
23 \\
25 \\
24 \\
39 \\
\\
\\
187 \\
242 \\
58 \\
95 \\
6 \\
2 \\
\end{tabular}

Item Percent Professional role

Procurement officer/personnel 23.6 Engineer 24.7 Quantity surveyor 10.7 Purchasing officer/personnel 5.9

Architect 5.4 Land surveyor 1.4 Administrator 9.5 Urban/Town planner 3.9 Estate surveyor 4.2 Builder 4.1 Other role 6.6

Highest Education

Pre-bachelor's degree education (secondary/diploma/HND) 31.7 Bachelor's degree 41.0

Postgraduate diploma 9.8 Masters/PhD degree 16.1 Other 1.0 Non-response 0.3

\section{Experience in professional role (years)}

0-5 42.0 6-10 $22.511-1513.116-2010.0$ Over 207.8

Non-response 4.6 Mean = 9.12; Standard deviation $=7.29$

Experience in infrastructure procurement (years)

0-5 47.6 6-10 21.7 11-15 6.6 Over 15 6.8 Non-response 17.3 Mean = 6.62; Standard

deviation $=5.70$ 
Table 4: Exploratory factor analysis results

\begin{tabular}{|c|c|c|}
\hline \multirow[t]{2}{*}{$\begin{array}{l}\text { Communaliti } \\
\text { es after } \\
\text { extraction }\end{array}$} & & $\begin{array}{l}\text { mponent } \\
\text { yanisatio } \\
\text { ocureme } \\
\text { capacity }\end{array}$ \\
\hline & 1 & 2 \\
\hline 0.631 & 0.724 & 0.763 \\
\hline 0.618 & 0.697 & 0.707 \\
\hline 0.660 & 0.690 & 0.694 \\
\hline 0.657 & 0.688 & 0.691 \\
\hline 0.658 & 0.685 & 0.657 \\
\hline 0.663 & 0.678 & 0.594 \\
\hline 0.647 & 0.654 & \\
\hline 0.628 & 0.644 & \\
\hline 0.540 & 0.548 & \\
\hline 0.725 & & \\
\hline 0.679 & & \\
\hline 0.679 & & \\
\hline 0.680 & & \\
\hline 0.651 & & \\
\hline 0.602 & & \\
\hline 0.555 & & \\
\hline 0.559 & & \\
\hline 0.642 & & \\
\hline 0.636 & & \\
\hline 0.638 & & \\
\hline 0.652 & & \\
\hline 0.643 & & \\
\hline 0.606 & & \\
\hline
\end{tabular}

\begin{tabular}{|c|c|c|}
\hline Eigen value & 11.817 & 1.669 \\
Variance & 51.377 & 7.255 \\
explained & 0.913 & 0.913 \\
Cronbach & & \\
alpha & & \\
\hline
\end{tabular}


Leadership and top management support for procurement

Inclusion and participation of civil society organisations

and media in the public procurement process

Inclusion and participation of private sector institutions

in procurement process

Highly motivated and satisfied procurement staff

Physical and logistical resources that support

procurement (e.g. means of transport, office space etc.)

Well remunerated /compensated procurement staff

Training and effective procurement personnel capacity

development

Computing and ICT facilities

Effective human resource management of procurement

staff

Number of qualified procurement personnel

Application of sustainability principles in procurement

(e.g. in specifications, tender selection criteria etc.)

Procurement rules and procedures that incorporate

lifecycle approach to analysis and costing 0.705 Capacity to self-finance projects (e.g. internally

generated funds or public/private partnerships) 0.683 Integration of procurement with internal financial

management and budgeting systems 0.681 Capacity to meet project payment obligations on time 0.659 Capacity for long term planning and allocation of funds

for procurement 0.644 Existence of policies aimed at promoting social or

environmentally responsible procurement 0.5771 .166

Notes:

Extraction method and rotation method are principal component analysis and varimax rotation, respectively.

$\mathrm{KMO}=0.953$. The variance explained by the three factors $=63.70 \%$.

Bartlett's Test of Sphericity: Chi-Square $=9373.783(\mathrm{df}=253), \mathrm{p}<0.001$.

The factor loadings less than 0.5 have been suppressed.

Table 5: Regression Results for the Relationship between Organisational Procurement Capacity and the Procurement Objectives

Procurement objective

(dependent variable)

ANOVA

$\mathrm{F}$

\begin{tabular}{|c|c|c|c|c|c|c|c|c|}
\hline \multicolumn{4}{|c|}{ Predictor variable co-efficient } & \multirow[b]{2}{*}{$\mathrm{R}$} & \multirow[b]{2}{*}{$\mathrm{R}^{2}$} & \multirow[b]{2}{*}{$\begin{array}{l}\text { Adjust } \\
\text { ed } R^{2}\end{array}$} & \multirow[b]{2}{*}{$\begin{array}{c}R^{2} \\
\text { Change }\end{array}$} & tic \\
\hline Constant & $\begin{array}{l}\text { Managem } \\
\text { ent of the } \\
\text { procurem } \\
\text { ent } \\
\text { process }\end{array}$ & $\begin{array}{l}\text { Human } \\
\text { and } \\
\text { physical } \\
\text { resources }\end{array}$ & $\begin{array}{c}\text { Financial } \\
\text { resources } \\
\text { and } \\
\text { management }\end{array}$ & & & & & \\
\hline
\end{tabular}




\begin{tabular}{|c|c|c|c|c|c|c|c|}
\hline $3.636^{*}$ & $0.330^{*}$ & $0.285^{*}$ & $0.237^{*}$ & 0.533 & 0.284 & 0.280 & 0.065 \\
\hline $3.629^{*}$ & $0.329^{*}$ & $0.259^{*}$ & $0.212^{*}$ & 0.546 & 0.298 & 0.294 & 0.061 \\
\hline $3.725^{*}$ & $0.290^{*}$ & $0.307^{*}$ & $0.238^{*}$ & 0.525 & 0.276 & 0.272 & 0.067 \\
\hline $3.482^{*}$ & $0.342^{*}$ & $0.288^{*}$ & $0.282^{*}$ & 0.552 & 0.305 & 0.302 & 0.087 \\
\hline $3.386^{*}$ & $0.330^{*}$ & $0.206^{*}$ & $0.346^{*}$ & 0.508 & 0.258 & 0.254 & 0.040 \\
\hline $3.501^{*}$ & $0.324^{*}$ & $0.275^{\star}$ & $0.313^{*}$ & 0.559 & 0.312 & 0.309 & 0.085 \\
\hline $3.580^{*}$ & $0.308^{*}$ & $0.298^{*}$ & $0.356^{*}$ & 0.599 & 0.359 & 0.356 & 0.103 \\
\hline $3.759^{*}$ & $0.313^{*}$ & $0.291^{*}$ & $0.306^{*}$ & 0.563 & 0.317 & 0.314 & 0.097 \\
\hline $3.708^{*}$ & $0.344^{*}$ & $0.236^{*}$ & $0.301^{*}$ & 0.564 & 0.319 & 0.315 & 0.067 \\
\hline $3.589^{*}$ & $0.399^{*}$ & $0.231^{*}$ & $0.374^{*}$ & 0.584 & 0.341 & 0.337 & 0.052 \\
\hline $3.664^{*}$ & $0.260^{*}$ & $0.268^{*}$ & $0.323^{*}$ & 0.537 & 0.288 & 0.284 & 0.080 \\
\hline $3.833^{*}$ & $0.237^{*}$ & $0.308^{*}$ & $0.314^{*}$ & 0.557 & 0.310 & 0.307 & 0.070 \\
\hline
\end{tabular}

Transparency $75.223^{*}$

Compliance $80.296^{*}$ Value-for-money $72.265^{*}$

Promotion of equality, diversity and opportunity (e.g. for SMEs,

marginalised groups in society etc.)

Private sector

participation

$83.336^{*} 65.951^{\star}$

Innovation $85.951^{\star}$ Sustainability $105.949^{\star}$ Accountability $88.001^{*}$

Standardisation of procurement procedures Competition in

procurement process

$88.519^{*} 98.017^{*}$

Cost effectiveness $76.744^{*}$ Professionalism $85.312^{*}$ Notes: ${ }^{*} p<0.001$ 